\title{
The Effect of Stage of Harvest and Storage on the Seed Quality of Chickpea (Cicer arietinum L.)
}

\author{
A. Khatun ${ }^{\mathrm{a} *}$, M. A. H. Bhuiyan ${ }^{\mathrm{b}}$ and M. M. Ud-deen ${ }^{\mathrm{c}}$ \\ ${ }^{a}$ Planning and Evaluation Division, ${ }^{b}$ Soil Science Division, Bangladesh Agricultural Research Institute, \\ Joydebpur, Gazipur-1701, Bangladesh and ${ }^{c}$ Department of Crop Science and Technology, University of Rajshahi, \\ Rajshahi-6205, Bangladesh
}

\begin{abstract}
Laboratory experiments were carried out to determine the effects of harvesting stages on the seed quality of chickpea. Chickpea seed of three varieties (BARI Chola-5, BARI Chola-6 and BARI Chola-8) were collected at three harvestings times i.e. from three different times at 7 days interval prior to harvesting, viz. i) when the pods were yellowish with a few yellow greens ( $\mathrm{H}_{1}$ stage), ii) when most of the pods were light brown with a few yellow $\left(\mathrm{H}_{2}\right.$ stage), and iii) when all the pods were completely brown and dry ( $\mathrm{H}_{3}$ stage). Significant variation was observed in three varieties of chickpea for all the parameters studied except vigour-I. The highest germination percentage, root length, shoot length, root plus shoot length and vigour-II was observed in BARI Chola-5 which was significantly higher over BARI Chola-8. Dry weight was found to be significantly higher in BARI Chola-8 which was identical to BARI Chola-6. Moisture content was significantly higher in BARI Chola-8. Seed collected at the stage when most of the pods were light brown with a few yellow $\left(\mathrm{H}_{2}\right.$ stage) recorded the highest germination percentage, dry weight, vigour-I and root length. Pods $\left(\mathrm{H}_{1}\right.$ stage) gave the highest moisture content in seeds. BARI Chola-5 seeds recorded the highest germination at $\mathrm{H}_{2}$ stage. Interaction effects of varieties and harvesting stage had non-significant effect on germination percentage, vigour-I, shoot length and vigour-II in both the years.
\end{abstract}

Keywords: Chickpea, Harvesting stage, Storage, Vigour, Moisture, Germination

\section{Introduction}

Seed development is the period between fertilizer and maximum fresh weight accumulation and seed maturation begins at the end of seed developments and continues till harvested (Mehta et al., 1993). The seed reaches its maximum dry weight at physiological maturity.

Storability of seed is mainly a genetical character and is influenced by pre-storage history of seed, seed maturation, environmental factors during pre and post harvest stages, etc. (Mahesha et al., 2001b). Early harvested seeds will be immature and poorly development and as such are poor storers compared to seed harvest at physiological maturity (Singh and Lachanna, 1995).

At physiological maturity, seed shall have maximum viability and vigour. Attainment of physiological maturity is a genotypic character which is influenced by environmental factors (Mahesha et al., 2001a). As such harvesting of seed crop at optimum stage of seed maturation is essential to obtain better seed quality.

Moisture content of harvested crop affects seed quality and hence it determines with which moisture content the crop should be threshed. Harvesting at high moisture content increases the changes of mycofloral infection on seed while harvesting at low moisture content increases mechanical damage to seed (Yadav et al. 2005). Seeds harvested at early were immature and poorly developed and as such are poor storers compared to seed harvested at physiological maturity (Mahesha et al., 2001a). Kumar et al. (2002) reported that seed yield and quality largely depends on the stage of maturity. As such, harvesting of seeds at right stage of maturity is most important since harvesting either at early or late stage results in lower yields with poor quality seeds.

Harvesting time of any crop for seed quality depends on its maturity time and on physiological maturity. Harvesting of

\footnotetext{
* Corresponding author: E-mail: mahbhuiyan63@yahoo.com
} 
seeds at optimum stage of maturity helps to obtain better quality seed. Harvesting stage influences the quality of seed in relation to germination, vigour, viability and also storability. Seed quality in storage is also influenced by the condition, which not yet studied for chickpea seed storage. Therefore, the investigation was carried out to find out the right time of harvest to ensure seed quality of chickpea.

\section{Materials and Methods}

Laboratory experiments were carried out at Seed Technology Division Laboratory in the Bangladesh Agricultural Research Institute (BARI), Joydebpur, Gazipur, Bangladesh during the period from August to September 2004 and 2005 to determine the effects of harvesting stages on seed quality of chickpea under laboratory conditions. Previously chickpea seeds of three varieties viz. BARI Chola-5, BARI Chola6 and BARI Chola-8 were collected from Pulses Research Centre experimental field of BARI, Bangladesh in rabi seasons of 2003-04 considering three different times of harvest at 7 days interval, viz. i) when the pods were yellowing with a few yellow greens ( $\mathrm{H}_{1}$ stage), ii) when most of the pods were light brown with a few yellow $\left(\mathrm{H}_{2}\right.$ stage), and iii) when all the pods were completely brown and dry $\left(\mathrm{H}_{3}\right.$ stage). The collected seeds were preserved in the earthen pot. Before setting up the field experiment, laboratory experiment was carried out for recording the seed quality data. Laboratorial experiments were conducted in Complete Randomized Design with the above seeds of chickpea. The following quality parameters (moisture \%, germination \%) and seed vigour contributing characters were recorded:

\section{Determination of moisture content}

The moisture content of seed samples were determined by ISTA, 1976. Grinded (10 g) seed samples each of chickpea were taken into moisture cup and put into a pre-heated oven at temperature of $103 \pm 2^{\circ} \mathrm{C}$ for one hour. Three replicates were taken. After cooling, the weight of the container with its cover and contents were taken. The seed samples were cooled in desiccators and weighed to work out the percent moisture content of the grains. The seed moisture content was determined by dry weight basis and was calculated by the following formula:

$\left\{\left(\mathrm{M}_{2}-\mathrm{M}_{3}\right) /\left(\mathrm{M}_{2}-\mathrm{M}_{1}\right)\right\} \times 100$

Where, $M_{1}$ is the weight in gram of the container and its cover,
$\mathrm{M}_{2}$ is the weight in gram of the container, its cover and its contents before drying, and $\mathrm{M}_{3}$ is the weight in gram of the container, its cover and contents after drying.

\section{Determination of germination test}

Germinations were carried out according to ISTA rule 1976. For each treatment, 100 seeds were put into petri dishes. Four replicates were used. The petri dishes were put up on a laboratory table at room temperature $\left(25 \pm 2^{\mathrm{O}} \mathrm{C}\right)$. After ten days, normal, abnormal and diseased seeds were counted.

\section{Measurement of root and shoot length}

After ten days, ten plants were randomly selected for study, taking from each replicate of each treatment. The seedlings were cut into root and shoot parts. They were measured (in $\mathrm{cm}$ ) and the mean value was computed.

\section{Determination of fresh and dry weight of seedling}

After measuring the root and shoot length as described above, fresh weight of seedlings was recorded. Then the root and shoot were put into paper packet separately, and placed into the preheated oven $\left(70^{\circ} \mathrm{C}\right)$ for 48 hours. After cooling in desiccators, the dry weight was taken.

\section{Determination of seed vigour}

Seedling vigour was calculated based on the following formulae (Reddy and Khan, 2001):

Vigour index-I: Percent germination $\mathrm{x}$ total dry weight of seedling.

Vigour index-II: Percent germination x length of seedling.

The data for different characters were compiled and tabulated in proper form and then subjected to statistical analysis following a computer IRRISTAT package programme adjusted the means. The correlation co-efficient were done for different variables wherever needed.

\section{Results and Discussion}

\section{Moisture percentage}

Observation on moisture percentage in three chickpea varieties revealed that varieties differed significantly among themselves (Table I). The highest moisture percentage 
Table I. Effects of different varieties of chickpea on different seed quality parameters

\begin{tabular}{|c|c|c|c|c|c|c|c|c|}
\hline Variety & $\begin{array}{c}\text { Moisture } \\
(\%)\end{array}$ & $\begin{array}{c}\text { Germi- } \\
\text { nation (\%) }\end{array}$ & $\begin{array}{c}\text { Dry } \\
\text { weight (g) }\end{array}$ & Vigour I & $\begin{array}{c}\text { Root } \\
\text { length }(\mathrm{cm})\end{array}$ & $\begin{array}{c}\text { Shoot } \\
\text { length }(\mathrm{cm})\end{array}$ & $\begin{array}{l}\text { Root + shoot } \\
\text { length }(\mathrm{cm})\end{array}$ & Vigour II \\
\hline 2004 & & & & & & & & \\
\hline BARI Chola-5 & $8.85 b$ & $86.2 \mathrm{a}$ & $0.45 b$ & 38.4 & $14.43 a$ & $12.84 a$ & $27.28 \mathrm{a}$ & 2351a \\
\hline BARI Chola-6 & $9.21 \mathrm{~b}$ & 83.3a & $0.49 \mathrm{ab}$ & 40.7 & $13.14 \mathrm{~b}$ & 12.63ab & $25.78 \mathrm{~b}$ & $2146 a$ \\
\hline BARI Chola-8 & $10.16 \mathrm{a}$ & $77.1 \mathrm{~b}$ & $0.53 a$ & 41.2 & $12.83 \mathrm{~b}$ & $11.58 \mathrm{~b}$ & $24.41 \mathrm{~b}$ & 1879b \\
\hline $\mathrm{SE}( \pm)$ & 0.167 & 2.05 & 0.015 & - & 0.250 & 0.258 & 0.335 & 55.1 \\
\hline Sig. & $* *$ & $*$ & $* *$ & NS & $* *$ & $* *$ & $* *$ & $* *$ \\
\hline 2005 & & & & & & & & \\
\hline BARI Chola-5 & $8.67 \mathrm{~b}$ & 86.0a & $0.46 \mathrm{~b}$ & 39.7 & 14.67 & $13.54 a$ & $28.21 \mathrm{a}$ & 2429a \\
\hline BARI Chola-6 & $8.87 \mathrm{~b}$ & 83.1a & $0.50 \mathrm{ab}$ & 42.0 & 13.27 & $13.27 \mathrm{a}$ & 26.53ab & 2207ab \\
\hline BARI Chola-8 & $10.69 a$ & $78.3 b$ & $0.55 a$ & 43.3 & 12.83 & $11.63 \mathrm{~b}$ & $24.47 \mathrm{~b}$ & 1918b \\
\hline $\mathrm{SE}( \pm)$ & 0.168 & 0.88 & 0.023 & - & - & 0.24 & 0.38 & 79.2 \\
\hline Sig. & $* *$ & $* *$ & $*$ & NS & NS & $* *$ & $* *$ & $* *$ \\
\hline
\end{tabular}

In a column, the figure(s) having same letter are not significantly different

*Significant at 5\% level, **Significant at 1\% level, NS: Not significant

(10.16\% in 2004 and $10.69 \%$ in 2005) was observed in BARI Chola-8, which was statistically different from BARI Chola- 5 and BARI Chola-6. The lowest moisture percentage (8.85\% in 2004 and 8.67\% in 2005) was observed in BARI Chola-5. Shahjahan (2003) observed that chickpea seed contained $8.74-13.40 \%$ moisture content after nine months of storing in six types of containers. Morshed et al. (2003) reported that chickpea seed contained 9.28-11.75\% moisture content after six months of storing. There was a highly significant effect of harvesting stage on moisture percentage (Table II). Pods collected at the stage of yellow with a few yellow green $\left(\mathrm{H}_{1}\right.$ stage) recorded higher moisture percentage (9.94\% in 2004 and $9.87 \%$ in 2005). The lowest moisture (8.84\% in 2004 and $9.20 \%$ in 2005) was observed by the seed that were collected at the stage of light brown with a few yellow green $\left(\mathrm{H}_{2}\right)$ and when all the pods were completely brown and dry $\left(\mathrm{H}_{3}\right)$, respectively. Mehta et al. (1993) reported that seed harvested at 29 days after anthesis (DAA) showed the highest moisture percentage while seed harvested at 45 DAA showed the lowest moisture percentage. Moisture content was the highest in $\mathrm{H}_{1}$ stage i.e. seed collected at 30 days after flowering (DAF) and the lowest moisture content in $\mathrm{H}_{3}$ stage i.e. at $40 \mathrm{DAF}$ (Mahesha et al., 2001a). The decrease in seed moisture content (Robertson et al., 1978), increase in test weight (Robertson et al., 1978) and germination percentage (Shete et al., 1992) were reported with the advancement of harvesting dates. The interaction between varieties and harvesting stages was significant for moisture percentage (Table III). Moisture percentage was the highest due to the interaction effect of BARI Chola- $8 \mathrm{x} \mathrm{H}_{3}$ in
2004 and BARI Chola- $8 \mathrm{x} \mathrm{H}_{2}$ in 2005. The lowest moisture percentage was observed in $\mathrm{V}_{1} \mathrm{H}_{2}$ in 2004, and in $\mathrm{V}_{2} \mathrm{H}_{2}$ and $\mathrm{V}_{2} \mathrm{H}_{3}$ in 2005.

\section{Germination percentage}

The tested chickpea varieties differed in germination percentage (Table I). Among three varieties, germination percentage was higher (86.2\% in 2004 and $86.0 \%$ in 2005) in BARI Chola-5 which was identical to BARI Chola-6. The lowest germination percentage $(77.1 \%$ in 2004 and $78.3 \%$ in 2005) was observed in BARI Chola-8. Morshed et al. (2003) reported that khesari seed gave $85.0-95.0 \%$ germination while mungbean seed gave 85.0-95.0\% germination percent after six months of storing. Bhingarde and Dumbre (1993) reported that large sized seed gave higher germination percentage (48\%) and smaller size seed gave lower germination percentage (46.0\%). Borate et al. (1993) observed that germination was higher (89.6\%) in large size seed and lower (85.2\%) in small size seed of groundnut. Mahesha et al. (2001b) reported that varieties differed significantly on germination percentage. Harvesting stage markedly did not markedly increase the germination percentage (Table II). Seed collected in $\mathrm{H}_{2}$ stage gave the highest germination percentage (83.4\% in 2004 and 83.5\% in 2005). The lowest germination percentage was observed in $\mathrm{H}_{1}$ stage. It indicated that germination was less in early harvested seed compared to seed harvested at later stages. Lesser germination (\%) attributes in early harvested seed may due to presence of more number of immature and unfilled seed. Harvesting the 
Table II. Effects of chickpea seeds collected from different harvesting stages on different seed quality parameters

\begin{tabular}{|c|c|c|c|c|c|c|c|c|}
\hline $\begin{array}{l}\text { Harvesting } \\
\text { Stage }\end{array}$ & \begin{tabular}{|c} 
Moisture \\
(\%)
\end{tabular} & $\begin{array}{c}\text { Germi- } \\
\text { nation (\%) }\end{array}$ & $\begin{array}{c}\text { Dry } \\
\text { weight (g) }\end{array}$ & Vigour I & $\begin{array}{c}\text { Root } \\
\text { length }(\mathrm{cm})\end{array}$ & $\begin{array}{c}\text { Shoot } \\
\text { length }(\mathrm{cm})\end{array}$ & $\begin{array}{l}\text { Root + shoot } \\
\text { length }(\mathrm{cm})\end{array}$ & Vigour II \\
\hline $\begin{array}{l}2004 \\
\mathrm{H}_{1} \\
\mathrm{H}_{2} \\
\mathrm{H}_{3} \\
\mathrm{SE}( \pm) \\
\text { Sig. }\end{array}$ & $\begin{array}{c}9.94 \mathrm{a} \\
8.84 \mathrm{~b} \\
9.46 \mathrm{ab} \\
0.167 \\
* *\end{array}$ & $\begin{array}{c}80.1 \\
83.4 \\
83.1 \\
- \\
\text { NS }\end{array}$ & $\begin{array}{c}0.49 \\
0.50 \\
0.48 \\
- \\
\text { NS }\end{array}$ & $\begin{array}{c}38.8 \\
41.5 \\
40.0 \\
- \\
\text { NS }\end{array}$ & $\begin{array}{c}13.17 \\
13.67 \\
13.58 \\
- \\
\text { NS }\end{array}$ & $\begin{array}{c}12.38 \mathrm{ab} \\
11.68 \mathrm{~b} \\
13.00 \mathrm{a} \\
0.258 \\
* *\end{array}$ & $\begin{array}{c}25.54 \mathrm{ab} \\
25.34 \mathrm{~b} \\
26.58 \mathrm{a} \\
0.335 \\
*\end{array}$ & $\begin{array}{c}2046 \\
2118 \\
2212 \\
- \\
\text { NS }\end{array}$ \\
\hline $\begin{array}{l}2005 \\
\mathrm{H}_{1} \\
\mathrm{H}_{2} \\
\mathrm{H}_{3} \\
\mathrm{SE}( \pm) \\
\text { Sig. }\end{array}$ & $\begin{array}{c}9.87 a \\
9.21 b \\
9.20 b \\
0.168 \\
*\end{array}$ & $\begin{array}{c}81.2 \\
83.5 \\
82.7 \\
- \\
\text { NS }\end{array}$ & $\begin{array}{c}0.50 \\
0.51 \\
0.50 \\
- \\
\text { NS }\end{array}$ & $\begin{array}{c}40.8 \\
42.5 \\
41.6 \\
- \\
\text { NS }\end{array}$ & $\begin{array}{c}13.07 \\
13.90 \\
13.80 \\
- \\
\text { NS }\end{array}$ & $\begin{array}{c}12.90 \\
12.94 \\
12.60 \\
- \\
\text { NS }\end{array}$ & $\begin{array}{c}25.97 \\
26.84 \\
26.40 \\
- \\
\text { NS }\end{array}$ & $\begin{array}{c}2113 \\
2248 \\
2193 \\
- \\
\text { NS }\end{array}$ \\
\hline
\end{tabular}

In a column, the figure(s) having same letter are not significantly different

*Significant at $5 \%$ level, **Significant at $1 \%$ level, NS: Not significant

$\mathrm{H}_{1}$ : When pods were yellow with a few yellow green

$\mathrm{H}_{2}$ : Most pods were light brown with a few yellow green

$\mathrm{H}_{3}$ : All the pods were completely brown and dry

crop earlier resulted in poor seed quality owing to immaturity (Jayaraj and Karivaratharaju, 1992). Mehta et al. (1993) reported that seed harvested at 37 to onwards of DAA recorded higher germination percentage while seed harvested at 33 DAA showed the lower germination percentage. They also observed that seed harvested before 33 DAA drastically reduced the germination percentage. Significant differences were also noted in germination due to harvesting. Seed collected 40 days after anthesis registered lowest germination (25.0\%) and it was the highest (91.3\%) on 60th day after anthesis (Jayaraj and Karivaratharaju, 1992). Germination percentage was the highest in $\mathrm{H}_{2}$ stage i.e. seed collected at 35 days after flowering (DAF) and the lowest in H1 stage i.e. at 30 DAF (Mahesha et al., 2001a, 2001b). The decrease in seed moisture content (Robertson et al., 1978), increase in test weight (Robertson et al., 1978) and germination percentage (Shete et al., 1992) were reported with the advancement of harvesting dates. In the present study, the highest germination percentage (89\%) was observed in 2004 by the interaction of BARI Chola- $5 \mathrm{x} \mathrm{H}_{2}$ and BARI Chola- $6 \mathrm{x} \mathrm{H}_{2}$, and $87.5 \%$ in 2005 by the interaction of BARI Chola- $5 \mathrm{x} \mathrm{H}_{3}$ (Table III). The lowest germination percentage was observed in interaction of BARI Chola$8 \times \mathrm{H}_{3}$. In all varieties, $\mathrm{H}_{2}$ gave the highest percentage and $\mathrm{H}_{1}$ gave the lowest.

\section{Dry weight}

Shoot dry weight of BARI Chola varieties was significant. BARI Chola-8 recorded the highest shoot dry weight, which was significant over BARI Chola-5 but identical to BARI Chola-6 (Table I). Tomar et al. (2000) reported that among four varieties of lentil genotype Pant L 639 recorded significantly higher dry weight. Effect of harvesting stage on dry weight was non-significant (Table II). The maximum shoot dry weight $\left(0.51 \mathrm{~g} \mathrm{plant}^{-1}\right.$ in 2005) was recorded in the harvesting stage of $\mathrm{H}_{2}$, which differed to $\mathrm{H}_{1}$. Dry weight was the highest in $\mathrm{H}_{2}$ stage i.e. seed collected at 35 days after flowering (DAF) and the lowest in $\mathrm{H}_{1}$ stage i.e. at $30 \mathrm{DAF}$ (Mahesha et al., 2001b). The effect of variety $\mathrm{x}$ harvesting stage on shoot dry weight was significant in 2004 (Table III). The maximum shoot dry weight (0.58 g plant ${ }^{-1}$ in 2004) was recorded by BARI Chola- $8 \times \mathrm{H}_{1}$, which was significantly different from all other treatments but identical to $\mathrm{V}_{1} \mathrm{H}_{3}$, $\mathrm{V}_{2} \mathrm{H}_{2}$, and $\mathrm{V}_{3} \mathrm{H}_{3}$ in 2004. The minimum shoot dry weight was observed in BARI Chola-5 $\mathrm{x} \mathrm{H}_{1}$ in 2004 and in BARI Chola-5 ${\text { x } \mathrm{H}_{2}}_{2}$ in 2005.

\section{Vigour-I}

The maximum vigour-I was produced by BARI Chola-8 (Table I). This might be due to higher germination percentage and dry weight. The lowest vigour-I (38.4 in 2004 and 
Table III. Interaction effects of chickpea varieties and seeds collected from different harvesting stages on different seed quality parameters

\begin{tabular}{|c|c|c|c|c|c|c|c|c|}
\hline Treatment & \begin{tabular}{|c} 
Moisture \\
$(\%)$
\end{tabular} & $\begin{array}{c}\text { Germi- } \\
\text { nation (\%) }\end{array}$ & $\begin{array}{c}\text { Dry } \\
\text { weight (g) }\end{array}$ & Vigour I & $\begin{array}{c}\text { Root } \\
\text { length }(\mathrm{cm})\end{array}$ & $\begin{array}{c}\text { Shoot } \\
\text { length }(\mathrm{cm})\end{array}$ & $\begin{array}{l}\text { Root }+ \text { shoot } \\
\text { length }(\mathrm{cm})\end{array}$ & Vigour II \\
\hline 2004 & & & & & & & & \\
\hline $\mathrm{V}_{1} \mathrm{H}_{1}$ & 9.81abc & 84.0 & $0.40 c$ & 33.7 & $15.20 \mathrm{a}$ & 13.07 & 28.27a & 2378 \\
\hline $\mathrm{V}_{1} \mathrm{H}_{2}$ & 7.90d & 89.0 & $0.44 \mathrm{~b}$ & 39.2 & 14.07ab & 12.17 & 26.23bcd & 2334 \\
\hline $\mathrm{V}_{1} \mathrm{H}_{3}$ & 8.85bcd & 85.7 & $0.50 \mathrm{ab}$ & 42.2 & 14.03ab & 13.30 & 27.33ab & 2339 \\
\hline $\mathrm{V}_{2} \mathrm{H}_{1}$ & 10.11ab & 78.0 & $0.48 \mathrm{bc}$ & 37.2 & 12.30cd & 13.00 & 25.30de & 1960 \\
\hline $\mathrm{V}_{2} \mathrm{H}_{2}$ & 8.85bcd & 83.0 & $0.53 a b$ & 44.2 & 13.23bcd & 12.13 & $25.37 d$ & 2103 \\
\hline $\mathrm{V}_{2} \mathrm{H}_{3}$ & 8.68cd & 89.0 & $0.46 \mathrm{bc}$ & 40.7 & 13.90ab & 12.77 & 26.67bc & 2376 \\
\hline $\mathrm{V}_{3} \mathrm{H}_{1}$ & 9.89abc & 78.3 & $0.58 \mathrm{a}$ & 45.4 & $12.00 \mathrm{~d}$ & 11.07 & $23.07 f$ & 1800 \\
\hline $\mathrm{V}_{3} \mathrm{H}_{2}$ & 9.76abc & 78.3 & $0.52 b$ & 41.0 & 13.70bc & 10.73 & $24.43 e$ & 1916 \\
\hline $\mathrm{V}_{3} \mathrm{H}_{3}$ & $10.84 a$ & 74.7 & $0.50 \mathrm{ab}$ & 37.1 & 12.80bcd & 12.93 & $25.73 c d$ & 1921 \\
\hline $\mathrm{SE}( \pm)$ & 0.289 & - & 0.027 & - & 0.433 & - & 0.580 & - \\
\hline Sig. & $* *$ & NS & $*$ & NS & $*$ & NS & $*$ & NS \\
\hline CV (\%) & 5.3 & 7.5 & 9.4 & 12.5 & 5.6 & 6.3 & 3.9 & 7.8 \\
\hline 2005 & & & & & & & & \\
\hline $\mathrm{V}_{1} \mathrm{H}_{1}$ & $9.10 \mathrm{bc}$ & 83.3 & 0.47 & 39.2 & 14.10 & 13.50 & 27.60 & 2301 \\
\hline $\mathrm{V}_{1} \mathrm{H}_{2}$ & $8.50 \mathrm{c}$ & 87.1 & 0.45 & 39.2 & 14.90 & 13.93 & 28.83 & 2512 \\
\hline $\mathrm{V}_{1} \mathrm{H}_{3}$ & $8.40 \mathrm{c}$ & 87.5 & 0.46 & 40.5 & 15.00 & 13.20 & 28.20 & 2474 \\
\hline $\mathrm{V}_{2} \mathrm{H}_{1}$ & $10.00 \mathrm{ab}$ & 82.1 & 0.49 & 40.3 & 12.80 & 13.40 & 26.20 & 2153 \\
\hline $\mathrm{V}_{2} \mathrm{H}_{2}$ & 8.30c & 85.1 & 0.52 & 44.3 & 13.30 & 13.30 & 26.60 & 2266 \\
\hline $\mathrm{V}_{2} \mathrm{H}_{3}$ & 8.30c & 82.0 & 0.50 & 41.3 & 13.70 & 13.10 & 26.80 & 2203 \\
\hline $\mathrm{V}_{3} \mathrm{H}_{1}$ & $10.50 \mathrm{a}$ & 78.2 & 0.55 & 43.0 & 12.30 & 11.80 & 24.10 & 1885 \\
\hline $\mathrm{V}_{3} \mathrm{H}_{2}$ & $10.83 a$ & 78.2 & 0.56 & 43.9 & 13.50 & 11.60 & 25.10 & 1967 \\
\hline $\mathrm{V}_{3} \mathrm{H}_{3}$ & 10.73a & 78.5 & 0.55 & 43.0 & 12.70 & 11.50 & 24.20 & 1902 \\
\hline $\mathrm{SE}( \pm)$ & 0.292 & - & - & - & - & - & - & - \\
\hline Sig. & $*$ & NS & NS & NS & NS & NS & NS & NS \\
\hline CV (\%) & 5.4 & 3.2 & 13.9 & 16.6 & 11.4 & 5.7 & 8.4 & 10.9 \\
\hline
\end{tabular}

In a column, the figure(s) having same letter are not significantly different *Significant at 5\% level, *Significant at 1\% level, NS: Not significant $\mathrm{V}_{1} \mathrm{H}_{1}$ : BARI Chola- $5 \mathrm{x}$ When pods were yellow with a few yellow green $\mathrm{V}_{1} \mathrm{H}_{2}$ : BARI Chola- $5 \mathrm{x}$ Most pods were light brown with a few yellow green $\mathrm{V}_{1} \mathrm{H}_{3}$ : BARI Chola-5 $\mathrm{x}$ All the pods were completely brown and dry $\mathrm{V}_{2} \mathrm{H}_{1}$ : BARI Chola- $6 \mathrm{x}$ When pods were yellow with a few yellow green $\mathrm{V}_{2} \mathrm{H}_{2}$ : BARI Chola- $6 \mathrm{x}$ Most pods were light brown with a few yellow green $\mathrm{V}_{2} \mathrm{H}_{3}$ : BARI Chola- $6 \mathrm{x}$ All the pods were completely brown and dry $\mathrm{V}_{3} \mathrm{H}_{1}$ : BARI Chola-8 $\mathrm{x}$ When pods were yellow with a few yellow green $\mathrm{V}_{3} \mathrm{H}_{2}$ : BARI Chola-8 $\mathrm{x}$ Most pods were light brown with a few yellow green $\mathrm{V}_{3} \mathrm{H}_{3}$ : BARI Chola-8 $x$ All the pods were completely brown and dry

39.7 in 2005) was noted in BARI Chola-5. Harvesting stage showed non-significant effect on vigour-I (Table II). Higher vigour-I was noted with $\mathrm{H}_{2}$ harvesting stage and the lowest were observed by $\mathrm{H}_{1}$. Harvesting the seed before the attainment of physiological maturity recorded lesser viability and vigour potentials due to more number of immature seeds with relatively low degree of embryo development and high moisture content as reported in pea by Matthews (1973)
Interaction of variety $\mathrm{x}$ harvesting stage on vigour-I showed non-significant (Table III). The highest seed vigour-I (45.4 in 2004 and 44.3 in 2005) was observed by the interaction of BARI Chola- $8 \mathrm{x} \mathrm{H}_{1}$ in 2004 and Chola- $6 \mathrm{x} \mathrm{H}_{2}$ in 2005. The lowest vigour-I was noted by the interaction of BARI Chola$5 \mathrm{x} \mathrm{H}_{1}$. 


\section{Root length}

The maximum root length $(14.43 \mathrm{~cm}$ in 2004) produced by BARI Chola-5 was significantly superior to other two varieties (Table I). In 2005, root length was also higher in BARI Chola-5 though the length was at par with other two varieties. The lowest root length was recorded by BARI Chola8. Singh (1992) observed that L 9-12 gave higher root length of $7.2 \mathrm{~cm}$ and HP L-5 gave the lower root length of $6.7 \mathrm{~cm}$. Harvesting stage produced non-significant root length (Table II) though the highest root length was recorded in the $\mathrm{H}_{2}$ stage and the lowest was found in $\mathrm{H}_{1}$. The interaction effect of harvesting stage on root length of three chickpea varieties revealed that root length was markedly improved by harvesting stages in all the varieties in 2004 (Table III). In BARI Chola-5, $\mathrm{H}_{1}$ harvesting stage resulted in maximum root length $(15.2 \mathrm{~cm})$ in 2004 and BARI Chola- $5 \mathrm{x} \mathrm{H}_{3}(15.0 \mathrm{~cm})$ in 2005. Interaction effect of BARI Chola- $8 \mathrm{x} \mathrm{H}_{1}$ recorded the lowest root length.

\section{Shoot length}

The maximum shoot length of $12.84 \mathrm{~cm}$ in 2004 and 13.54 $\mathrm{cm}$ in 2005 was produced by BARI Chola-5, which was identical to BARI Chola-6 (Table I). The lowest shoot length was noted in BARI Chola-8. Singh (1992) observed that L 9-12 gave higher shoot length of $9.8 \mathrm{~cm}$ and HP L-5 gave the lower shoot length of $8.6 \mathrm{~cm}$. Significantly higher shoot length $(13.0 \mathrm{~cm})$ was produced with $\mathrm{H}_{3}$ in 2004 (Table II). But in 2005, shoot length was also higher with $\mathrm{H} 2$ though the value was non-significant. Interaction of variety $\mathrm{x}$ harvesting stage did not differ significantly in respect of shoot length (Table III). The highest shoot length of $13.30 \mathrm{~cm}$ was recorded by the interaction of $\mathrm{V}_{1} \mathrm{H}_{3}$ in 2004 and of $13.93 \mathrm{~cm}$ by the interaction of $\mathrm{V}_{1} \mathrm{H}_{2}$ in 2005. The lowest shoot length was observed in $\mathrm{V}_{3} \mathrm{H}_{2}$ in 2004 and $\mathrm{V}_{3} \mathrm{H}_{3}$ in 2005 .

\section{Root plus shoot length}

The maximum root plus shoot length $(27.28 \mathrm{~cm}$ and 28.21 $\mathrm{cm}$ in 2004 and 2005) was noted by BARI Chola-5, which was significantly superior to BARI Chola-8 (Table I). Mahesha et al. (2001b) reported that varieties differed significantly on seedling length. Harvesting stage produced significantly higher root plus shoot length only in 2004 (Table II). The highest root plus shoot length was recorded in $\mathrm{H}_{2}$ stage (2005), which might have been resulted from higher germination percentage and vigorous growth. Seedling length (root plus shoot length) was the highest in $\mathrm{H}_{2}$ stage i.e. seed collected at 35 days after flowering (DAF) and the lowest in $\mathrm{H}_{1}$ stage i.e. at 30 DAF (Mahesha et al., 2001b). The effect of harvesting stage on root plus shoot length of three chickpea varieties revealed that root plus shoot length was markedly improved by harvesting stages in all the varieties in 2004 (Table III). The maximum root plus shoot length was observed by the interaction of $\mathrm{V}_{1} \mathrm{H}_{1}$ in 2004 and by $\mathrm{V}_{1} \mathrm{H}_{2}$ in 2005. The minimum root plus shoot length was noted in $\mathrm{V}_{3} \mathrm{H}_{1}$.

\section{Vigour-II}

BARI Chola-5 gave significantly higher vigour-II over BARI Chola-8 (Table I). Lower vigour-II was noted in BARI Chola-8. Decreased of the vigour-II in BARI Chola-8 might be due to lower germination percentage and root plus shoot length (Khare and Satpute, 1999). Similar varietal difference was reported by Matthews (1973) in peas. Borate et al. (1993) observed that vigour-II was higher (2568) in large size seeds and lower (2111) in small size seed of groundnut. Harvesting stage of $\mathrm{H}_{2}$ did not markedly increase vigour-II (Table II). Seeds harvested at the stage of light brown with a few yellow green of pods $\left(\mathrm{H}_{2}\right)$ showed numerically higher seed vigour-II, probably due to associative effect of germination percentage and seedling length. Increased seed vigour-II might be due to maturation of seeds in $\mathrm{H}_{2}$ stage resulting in improvement of germination percentage and seedling length (Gore et al., 1997). The vigour index showed a steady increase from 1592 to 26454 with the advancement of days after anthesis from 40 to 60 . The highest seed put value vigour-II (2378 and 2512) was recorded by interaction of $\mathrm{V}_{1} \mathrm{H}_{1}$ in 2004 and by $\mathrm{V}_{1} \mathrm{H}_{2}$ in 2005 (Table III). The lowest seed put value vigour-II (1800 in 2004 and 1885 in 2005) was noted by $\mathrm{V}_{3} \mathrm{H}_{1}$.

\section{Correlation}

Correlation matrix among the plant characters of chickpea has been shown in Table IV. A positive and significant correlation was observed between germination percentage and vigour-I (2004), root plus shoot length (2005), vigour-II (2004 and 2005); dry weight and vigour-I (2004 and 2005), root plus shoot length (2004 and 2005), vigour-II (2004 and 2005); vigour-I and root plus shoot length (2005), vigour-II (2005); root plus shoot length and vigour-II (2004 and 2005). A negative correlation was found between moisture percentage and germination percentage, vigour-I (2004), root plus shoot length (2004), vigour-II (2004). Similar negative correlatios was observed between germination percentage and 
Table IV. Correlation matrix among different parameters of chickpea

\begin{tabular}{|c|c|c|c|c|c|c|}
\hline \multirow[t]{2}{*}{ Characters } & \multirow[b]{2}{*}{ Year } & \multicolumn{5}{|c|}{ Correlation coefficient (r value) } \\
\hline & & Germination & Dry weight & Vigour-I & Root + shoot length & Vigour-II \\
\hline Moisture & $\begin{array}{l}2004 \\
2005\end{array}$ & $\begin{array}{l}-0.289 \\
-0.052\end{array}$ & $\begin{array}{c}0.200 \\
0.590^{* *}\end{array}$ & $\begin{array}{c}-0.015 \\
0.608 * *\end{array}$ & $\begin{array}{c}-0.315 \\
0.336\end{array}$ & $\begin{array}{c}-0.118 \\
0.296\end{array}$ \\
\hline Germination & $\begin{array}{l}2004 \\
2005\end{array}$ & & $\begin{array}{c}-0.266 \\
-0.043 n s\end{array}$ & $\begin{array}{c}0.431^{*} \\
0.259 \mathrm{~ns}\end{array}$ & $\begin{array}{c}-0.130 \\
0.656^{* *}\end{array}$ & $\begin{array}{c}0.460 * \\
0.798^{* *}\end{array}$ \\
\hline Dry weight & $\begin{array}{l}2004 \\
2005\end{array}$ & & & $\begin{array}{l}0.754 * * \\
0.944 * *\end{array}$ & $\begin{array}{c}0.257 \\
0.403^{*}\end{array}$ & $\begin{array}{l}-0.199 \\
0.403^{*}\end{array}$ \\
\hline Vigour-I & $\begin{array}{l}2004 \\
2005\end{array}$ & & & & $\begin{array}{c}-0.356 \\
0.615^{* *}\end{array}$ & $\begin{array}{c}0.121 \\
0.55^{* *}\end{array}$ \\
\hline $\begin{array}{l}\text { Root }+ \text { shoot } \\
\text { length }\end{array}$ & $\begin{array}{l}2004 \\
2005\end{array}$ & & & & & $\begin{array}{c}0.338 * \\
0.967 * *\end{array}$ \\
\hline
\end{tabular}

** Significant at $1 \%$ level, * Significant at $5 \%$ level

dry weight (2004 and 2005), root plus shoot length (2004), and dry weight and vigour-II (2004). A positive correlation $(r=0.596)$ between germination and dry matter was shown (Mehta et al., 1993). They also observed that germination showed negative correlations $(r=0.856)$ with moisture content of seed and $(r=0.573)$ with fresh weight of pod wall. Reddy and Khan (2001) found a positive and significant correlation between germination and seedling dry weight $(0.68 * *)$, vigour index-I $\left(0.91^{* *}\right)$ and vigour index-II $(0.97 * *)$.

\section{Conclusion}

The highest germination percentage, root length, shoot length, root plus shoot length and vigour-II was observed in BARI Chola-5 which was significantly higher over BARI Chola-8 and the lowest in BARI Chola-8. Seed collected at the stage when most of the pods were light brown with a few yellow $\left(\mathrm{H}_{2}\right.$ stage) recorded the highest germination percentage, dry weight, vigour-I and root length. Pods collected at the stage of yellow with a few yellow green $\left(\mathrm{H}_{1}\right.$ stage) gave the highest moisture content in seeds. BARI Chola-5 seeds collected $\left(\mathrm{H}_{2}\right.$ stage $)$ recorded the highest germination.

\section{References}

Bhingarde M. T. and Dumbre A. D. (1993) Effect of seed size on growth and yield components in greengram (Vigna radiata L. Wilczek) under summer conditions. Seed Res. 21(2): 104-106.
Borate D. N., Dumbre A.D. and Bhingarde M. T. (1993) Effect of seed size on growth, yield and seed quality of groundnut (Arachis hypogaea L.) under summer conditions. Seed Res. 21(2): 107-109.

Gore S. V., Patil R. B. and Wankhade G. R. (1997) Effect of maturity period and harvesting time on seed quality in soybean (Glycine max. [L.] Merill) cultivars. Seed Res. 25(1): 45-49.

ISTA (International Seed Testing Association). (1976) International Rules for Seed Testing. Seed Sci. and Tech. 4: 3-49.

Jayaraj T. and Karivaratharaju T. V. (1992) Influnce of harvesting stage on seed vigour in groundnut cultivar. Seed Res. 20(1): 41-43.

Khare D. and Satpute R. G. (1999) Influence of days to maturity and seed size on germination and seedling vigour in pigeonpea. Seed Res. 27(2): 170-173.

Kumar V., Shahidhan S. D., Kurdikeri M. B., Channaveeraswami A. S. and Hosmani R. M. (2002) Influence of harvesting stages on seed yield and quality in paprika (Capsicum annuum L.). Seed Res. 30(1): 99-103.

Mahesha C. R., Channaveeraswami A. S., Kurdikeri M. B., Shekhargouda M., and Merwade M. N. (2001a) Seed maturation studies in sunflower genotypes. Seed Res. 29(1): 95-97. 
Mahesha C. R., Channaveeraswami A. S., Kurdikeri M. B., Shekhargouda M. and Merwade M. N. (2001b) Storability of sunflower seeds harvested at different maturity dates. Seed Res. 29(1): 98-102.

Matthews. S. (1973) The effect of time of harvest on the viability and pre-emergence mortality in soil of pea (Pisum sativum L.) seeds. Ann. Appl. Biol. 73(2): 211219.

Mehta C. J., Kuhad M. S., Sheoran I. S. and Nandwal A. S. (1993) Studies on seed development and germination in chickpea cultivars. Seed Res. 21(2): 89-91.

Morshed M .S., Begum M., Bashar M. A. and Sultana, W. (2003) Effect of storage containers on seed quality of three pulses. Bangladesh J. Life Sci. 15(1): 107-112.

Reddy Y. T. N., and Khan M. M. (2001) Effect of osmopriming on germination, seedling growth and vigour of khirni (Mimusops hexandra) seeds. Seed Res. 29(1): 24-27.

Robertson J. A., Chapman J. V. G. R. and Nwilson J. R. R. L. (1978) Relation of days after flowering to chemical composition and physiological maturity of sunflower seed. Amer. Oil Chemist Soc. J. 35: 266-269.
Shahjahan M. (2003) Storage effect on the nutritional quality of three major pulses. Ph. D. Thesis, Department of Biochemistry and Molecular Biology, University of Dhaka.

Shete D. M., Singh A. R., Suryawanshi A. P. and Hudge V. S. (1992) Seed germination and vigour as influenced by seed position and stage of harvest in sunflower. Annals of Plant Physiol. 6: 125-132.

Singh N. (1992) Genotype x environment interaction for seed germination and seeding vigour in upland cotton. Seed Res. 20(1): 7-9.

Singh A. R., and Lachanna A. (1995) Effect of dates of harvesting, drying and storage on seed quality of sorghum parental lines. Seed Res. 13: 180-185.

Tomar S. K., Tripathi P. and Rajput A. L. (2000) Effect of genotype, seeding method and diammonium phosphate on yield and protein and nutrient uptake by lentil (Lens culinaris). Indian J. Agron. 45(1): 148-152.

Yadav S. K., Yadav S., Kumar P. R. and Kant K. (2005) A critical overview of chickpea seed technological research. Seed Res. 33(1): 1-15.

Received : August, 18, 2008;

Accepted : February 17, 2009 